\title{
3-tert-butoxycarbonylamino-pyridine-2-carboxylic Acid Methyl Ester
}

\section{Rachid Mamouni $^{\text {a,c,*, Mohammadine El Haddad }}{ }^{\text {b,c }}$ and Mohamed Akssira ${ }^{\text {c }}$}

a Faculté des Sciences, Université Ibn Zohr, BP 8061, 8000, Agadir, Morocco

b Faculté Poly-disciplinaire de Safi, Université Cadi Ayyad, BP 4162, 46000 Safi, Marocco

c Laboratoire de Chimie Bioorganique \& Analytique, FSTM, Université Hassan II -Mohammedia,BP 146, 20800 Mohammedia, Morocco

* Author to whom correspondence should be addressed. Fax: +(212) 048220100; E-mail: marach2001@yahoo.fr

Received: 23 January 2006 / Accepted: 24 February 2006 / Published: 30 May 2007

Keywords: Curtius rearrangement, Pyridopyrimidine, bioactivity

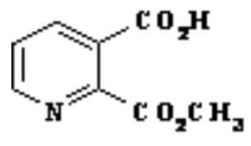

$\mathbf{1}$

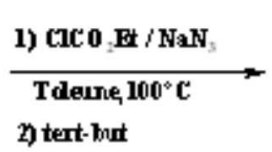

n) tert-bur

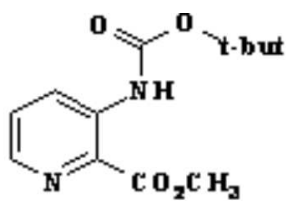

1

The discussion and purpose for the synthesis of the 2, 3-pyridinecarboxylicacid-2-methylester 1 has been reported elsewhere [1]. To a solution of half-ester $(1.0 \mathrm{~g}, 5.52 \mathrm{mmol})$ in dry tetrahydrofuran $(15 \mathrm{ml})$ cooled at $-10^{\circ} \mathrm{C}$ was added drop-wise triethylamine $(1.52 \mathrm{ml}, 11.04 \mathrm{mmol})$ then ethyl chloroformate $(0.79$ $\mathrm{ml}, 8.28 \mathrm{mmol})$. The mixture was stirred for 30 minutes at $-10^{\circ} \mathrm{C}$. Analysis by tlc showed complete conversion to a very non-polar product. A solution of sodium azide $(0.61 \mathrm{~g}, 9.38 \mathrm{mmol})$ in water $(4 \mathrm{ml})$ was then added drop wise continued stirring for $1 \mathrm{~h}$ at $-10^{\circ} \mathrm{C}$. The resulting mixture was filtered, evaporated and the aqueous phase was extracted with ethyl acetate $(3 \times 15 \mathrm{ml})$. The combined organic layer were washed with brine, dried $\left(\mathrm{MgSO}_{4}\right)$, filtered and concentrated in vacuo. The acyle azide was slowly brought to reflux in toluene for $2 \mathrm{~h}$ to give by Curtius rearrangement cleanly isocyanate. The subsequent reaction of isocyanate with 2-Methyl-2-propanol at $100^{\circ} \mathrm{C}$ for 3 hours. After evaporation in vacuo, the crude product was purified by chromatography on silica gel $(9 / 1:$ EtOAc/petroleum ether) to give 3-tert-Butoxycarbonylamino-pyridine-2-carboxylic acid methyl ester 2 (1.03 g, 80\%).

$\mathrm{R}_{\mathrm{f}} 0.36$ (9:1, EtOAc/petroleum ether)

Melting point: $94^{\circ} \mathrm{C}$ (pale white crystals, from hexane)

IR $\left(\mathrm{KBr}, \mathrm{v}, \mathrm{cm}^{-1}\right):$ 3298, $3000(\mathrm{NH}), 1721,1691(\mathrm{CO})$.

${ }^{1}$ H-NMR (300 MHz, DMSO-d $\left.6, \delta, p p m\right): 1.47$ (s, 9H, CH3), 3.85 (s, 3H, CH3), 7.55 ( dd, 1H, J= 8.5, 4.3 Hz, H-5), 8.32 (dd, 1H, $J=4.3,1.3 \mathrm{~Hz}, \mathrm{H}-4), 8.41$ (dd, $1 \mathrm{H}, J=8.5,1.3, \mathrm{H}-6), 9.90$ (s, 1H, NH).

${ }^{13} \mathrm{C}$ - NMR (75 MHz, DMSO-d $\left.6, \delta, \mathrm{ppm}\right): 27.82\left(3 \mathrm{CH}_{3}\right), 52.44\left(\mathrm{CH}_{3} \mathrm{O}\right), 80.62\left(\mathrm{C}^{\left(\mathrm{CH}_{3}\right)}\right)$ ), 127.54, 127.71, $134.25,137.28,142.25,152.17,167.00$ (CO).

MS m/z: $253[\mathrm{M}+1], 197.5,165.0,153.0,139.0,121.5$. 
Elemental analysis: Calculated $\mathrm{C}_{12} \mathrm{H}_{16} \mathrm{~N}_{2} \mathrm{O}_{4}: \mathrm{C}, 57.13 ; \mathrm{H}, 6.39 ; \mathrm{N}, 11.10$ Found: $\mathrm{C}, 57.21 ; \mathrm{H}, 6.45 ; \mathrm{N}$, 11.07 .

\section{Acknowledgements}

We wish to thank the ministry ESRSFC of the Moroccan Government (PROTARS-P2T2/07) for financial support.

\section{References}

1. Mamouni, R.; Aadil, M.; Akssira, M.; Lasri, J.; Sepulveda-Arques, J. Tetrahedron Lett. 2003, 44, 2745-2747.

(C) 2007 by MDPI (http://www.mdpi.org/). Reproduction is permitted for noncommercial purposes. 